\title{
Assessing the Anti-corruption Strategies: Theoretical and Empirical Models
}

\author{
Prof. Ani Matei (Corresponding author) \\ Faculty of Public Administration \\ National School of Political Studies and Public Administration \\ Str. Povernei no 6, sector 1, Bucharest, Romania \\ Tel: +4-021-318-0894Ｆax:+4-021-314-6507Ｅ-mail: amatei@snspa.ro \\ Prof. Lucica Matei \\ Faculty of Public Administration \\ National School of Political Studies and Public Administration \\ Str. Povernei no 6, sector 1, Bucharest, Romania \\ Tel: +4-021-318-0894Ｆax: +4-021-314-6507Ｅ-mail: 1matei@snspa.ro
}

Received: September 13, $2010 \quad$ Accepted: January 18, 2011 doi:10.5430/jms.v2n1p23

\begin{abstract}
The preoccupations about conceiving and promoting efficient anti-corruption strategies exist in most states, especially in the developing countries.

The opportunity of such strategies derives from the direct link, demonstrated theoretically and empirically, between the effects of the anti-corruption strategies and government performance, translated both in the economic and social results and living standard, welfare etc.

In the last decades, the transnational actors - UN, World Bank, OECD, EU etc. - have affirmed as promoters of own anti-corruption strategies, directing the states' efforts, conferring adequate levels of relevance, effectiveness, efficiency or sustainability.

The South-Eastern European states incorporate own anti-corruption strategies in the framework of general strategies, aiming the government reform in the context of the European integration process.

Strengthening the public integrity, reducing corruption, developing a genuine climate of economic freedom become important objectives concerning the impact on government performance.

The paper incorporates briefly the main characteristics of anti-corruption strategies, developed by transnational actors and it aims to shape theoretical and empirical frameworks for the assessment of anti-corruption strategies.

The focus on some South-Eastern European states has a demonstrative character, as the presented analyses may be extended to various geo-political areas.
\end{abstract}

Keywords: Anti-corruption strategies, Assessment, Impact, Government performance

\section{Introduction}

Corruption, through extended and diversified forms of expression has become an object of study and analysis, both for experts, analysts and public authorities and institutions. The latter, concerned by the effects of corruption on the social and economic development have aimed and achieved a series of anti-corruption strategies, focused on combating and eliminating the causes of corruption, thus also their consequences. For the public organizations, found frequently in public administrations and generally in the public sector, theories have been formulated aimed at minimization of the corruption phenomena.

The governance processes and corruption phenomena are in a direct connection and benefit of profound analyses. Dealing corruption from the economic, cultural or political perspective, Rose-Ackerman (2005, 4-5) reveals four dimensions: 
- The first one is carried out on the background of public organisations, state and society, where corruption could create inefficiency and inequity. The purpose of reforms is not to eliminate corruption but to improve state efficiency, fairness and legitimacy. In this context, it is worth to mention a fundamental idea for the anti- corruption strategies: "the total elimination of corruption will never be worthwhile, but steps can be taken to limit its reach and reduce the harms it causes"

- Corruption has different meanings in different societies. It is difficult to establish a clear border between legal and illegal, between merit and bribe.

- How the basic structures of the public and private sector can produce or repress corruption. The prospect of a reform will change both the constitutional structures and the fundamental relation between market and state.

- The difficulty of reform for public or governmental organisations and the role of the international community in reform. The internal reform policy is essential, and between various organisations valuable lessons can be transferred even if the conditions are not always similar.

Although the author asserts: "this book does not present a blueprint for reform", she suggests "a range of alternatives that reforms must tailor to the conditions in individual countries". However "reform should not be limited to the creation of integrity systems" and "the primary goal should be to reduce the underlying incentives to pay and receive bribes, not to tighten systems of ex post control".

Previously to Rose-Ackerman's assertions, Banfield $(1975,593)$ analyses the key features that a public organization should meet in order to minimize corruption. Briefly, they are:

- the executive agents are selected on the basis of probity and institutional loyalty;

- $\quad$ there is a complete set of positive motivations for the loyal public service (including a high salary);

- $\quad$ there is a complete set of negative motivations, applied compulsory when corrupt acts were already identified;

- the goals and missions for a job are formulated clearly and univoque by director;

- the agents hold the necessary discretion for executing the job tasks;

- no ambiguities in rules;

- $\quad$ the director monitors the agent's performance;

- if there is the smallest doubt about the agent's probity, he/she is dismissed;

- $\quad$ the director, on his/her turn is also monitored.

The preoccupations of international organisations may be added to the above contributions, substantiating anti-corruption strategies at the level of government or sectoral public organisations. In this respect, the World Bank has asserted as an important and competent actor in the analysis concerning the causes and consequences of corruption. The control of corruption has become a core indicator of governance and the strategies grounded on this indicator represent pillars for national authorities.

The World Bank promotes good governance and anti-corruption actions as important pillars for reducing the poverty. The World Bank sustains the national or regional efforts for public integrity, minimization of corruption, as well as awarding assistance to countries in view of governance improvement and control of corruption, by means of the World Bank Institute (WBI).

The preoccupations about designing and promoting anti-corruption policies and strategies as well as evaluating the causes/consequences of the corruption phenomenon are also present in the European Union, OECD or other transnational bodies such as International Monetary Fund, USAID, Transparency International, Heritage Foundation etc.

\section{Basic Approaches to Anti-corruption}

McCusker (2006) achieves a review of anti-corruption strategies.

McCusker's paper reassesses and valorises relevant contributions, both of the transnational actors (Word Bank, IMF, OECD, UNDP, Transparency International etc.) as well as of authors recognised for their publications analysing the causes and consequences of corruption and defining the directions of action for the fight against corruption.

Structured in several chapters, the most important ones for our study are as follows: assessment and design, implementation and impact assessment, specific methods and measures etc.

The above author draws attention to the fact that in designing an anti-corruption strategy, it is imperative to be aware of the fundamental characteristics and nature of corruption itself. 
Three key schools of thought on corruption reduction and prevention are emphasised (McCusker, 2006, 8-9):

- Interventionism, in which the relevant authorities wait for the corrupt action to occur and then intervene to capture and punish the offender. This school stimulates retribution, rehabilitation and deterrence but there remain a number of obstructive variables including:

- $\quad$ the harm has already occurred and cannot be undone;

- $\quad$ the majority of crimes remain unreported;

- the demand on finite resources will inevitably be infinite given the degree of supervision necessary ensure that the deterrence effect operates.

- Managerialism, in which those individuals or agencies seeking to engage in corrupt behaviour can be discouraged or prevented from doing so by establishing appropriate systems, procedures and protocols. In essence, managerialism advocates the reduction or elimination of opportunities such that those who generally benefit from them cease to be able to do so. There are limitations with this school of thought also, key amongst which are the fact that individuals do not necessarily operate according to the predetermined principles of managerialism. Organisations contain three broad categories of people who will react differently to corrupt influences:

- $\quad$ category I: people who want to do the right thing and require guidance on how to achieve this;

- $\quad$ category II: people who are too timid to take the risk of operating outside set rules;

- $\quad$ category III: people who are corrupt and will operate outside of the rules entirely.

- Organisational Integrity which involves the integration of an organisation's operational systems, corruption control strategies and ethical standards so that a norm of ethical behaviour is created. This school of thought presupposes that deviance stems from the organisation rather than the individuals of which it is comprised, as if the breach of ethics involved in corrupt practices occurs almost by osmosis from the malfeasant organisation to the innocent individual within it. Arguably, targeting individuals in anti-corruption efforts is likely to be less successful than targeting the organisational context in which individuals operate.

The same author highlights other two aspects that may substantiate the national anti-corruption strategies

- $\quad$ corruption as a system of interlocking vicious cycles (Figure 1);

- causes of public corruption and fraud have different importance related to the level of income in every country (Table 1).

\author{
$<$ Figure 1 about here $>$ \\ $<$ Table 1 about here $>$
}

Karklins (2005) proposes an own scenario for the game theory in view to substantiate the anti-corruption strategies.

Karklins's chart $(2005,150)$ assumes:

- a structure based on three pillars - corrupter, corruptee, third actor - placed in different hypostases of winner or loser;

- understanding the interactions between each actor within a succession of scenarios that will form the anti-corruption strategy.

In Table 2, $\mathrm{A}$ and $\mathrm{B}$ can be either a citizen or an official. $\mathrm{C}$ can be another citizen, competitor, supervisor or the public at large.

$<$ Table 2 about here>

\title{
3. Models of the Assessment Frameworks for the Anti-corruption Strategies
}

The models presented below aim the most relevant examples of assessment of the anti-corruption strategies, usually designed and promoted at the initiative of transnational actors such as World Bank or European Bank for Reconstruction and Development. Of course the models presented, belong to authors recognised for their contributions and expertise in the study on corruption and anti-corruption. McCusker (2006, 36-76) presents a comprehensive list of the most recognised contributions in the mentioned fields. For the needs of our study, we shall approach Huther and Shah (2000), Steves and Rousso (2003), Shleifer and Vishny (1993), Gamboa-Cavazos et al. (2006) as well as Matei (2006), Andrei, Matei and Rosca (2009, Ch. 6, 143-161) or Matei and Matei (2009). 


\subsection{Corruption market as support of the models for assessing the anti-corruption strategies}

The "corruption market" is up to present an abstract model, difficult for operationalisation in empirical studies. However, it draws attention to the need to emphasise the possible actors and scenarios of corruption in view to be able to substantiate models of assessment of the anti-corruption strategies.

Regarding the relation between government performance and corruption, other papers also confirm the non-linear character of this relation and the fact that "at low or high levels of performance of a ruling party or politician, the corruption is more intense, while at intermediate levels, is weaker" (Gamboa-Cavazos et al., 2006).

Moreover, the study already mentioned discovers that the firms that accumulate more incomes from their industries are those willing to offer more bribery, fact also directly related to the political stability. The relation between the corrupt and the corruptor is bivalent in the sense that each of the two actors may be an active actor. As such, the reality confirms that for instance, in the case of the firms in economic decline, the public persons pretend higher payments for corruption. In a mutual way, the entrepreneurs have the impulse to bribe the officials with stable and long term political horizons. For those, the supply for corruption is increasing both in number and effective value.

Most of the times, in the relation established between the corrupt and the corruptor, negotiation and intermediation usually occur under the form of traffic of influence where public or private persons are involved.

As such, we can talk of a corruption market which may appear at the interface between the public and private. The dimensions of this market differ from one country to another and depend on different factors, amongst which we found the ones described in the previous sections.

The corruption market is based itself on several principles to which one can add or further detail (Matei, 2006, 8-9; Andrei, Matei and Rosca, 2009, 153-158):

- The existence of a demand and supply of corruption. Usually, goods that are offered or requested are public goods, public services, or different forms for facilitating access to the ownership of public goods or services (usually described by obtaining licenses, approvals, etc.). Even though they do not explicitly imply the existence of a market for corruption, Shleifer and Vishny (1993) analyze corruption in the context offered by the demand and supply of public goods. They suggest that there is a competition between a seller and a buyer which enables the extension of corruption.

- The mechanisms that regulate the functioning of the corruption market are not legal or visible and generally, refer to law imperfections, lack of control from legal instances and of course, favourable attitude to corrupt or being corrupted, adopted by public or private persons;

- In relation to the intensity of the ratio between the demand and supply of corruption, there is a price of corruption expressed, usually, by bribery. The appearance of such a price differs from the one to be found in economic theory and basis itself upon factors related to economic circumstances, opportunity of public interventions, etc., as well as power and political and administrative position of the one corrupted.

The above principles have been taken into account, even though, not explicitly, by other authors, as well. We refer here to Campante (2005) or Gamboa - Cavazos (2006).

As in any other market, the actors try to maximize their profits. As such, for the offer of corruption where the actor is a public person, politician, governmental official, etc., the evaluation tendency will increase, while for the demand, having as an actor a private person, an entrepreneur, owner of private employee, the evaluation tendency of the opportunity of corruption will decrease.

\subsection{Models for assessing the anti-corruption strategies developed by the World Bank}

\subsubsection{A Simple Evaluation Framework - Huther-Shah Model}

The model described below is broadly presented in Huther and Shah (2000, 2-8).

The economic support of the proposed assessment framework consists in an adapted version of the cost-benefit analysis. We also find additional considerations on the use of the cost-benefit analysis in view of assessing the anti-corruption strategies in Matei and Matei (2009).

Coming back to Huther and Shah (2000) paper, the core ideas will be synthesised below.

Focusing their entire approach on the corruption aspects in the development programmes achieved with World Bank assistance, the authors propose an assessment framework based on "the incentives for opportunistic behaviour by public officials" (Huther and Shah, 2000, 2). 
In order to make distinction between grand corruption and societies without corruption, to a large extent, the authors take into consideration the conditions where the officials search or accept corruption:

- the expected gains exceed the estimated costs for achieving a corruption act;

- little weight is placed on the costs that corruption imposes on others.

Those two conclusions have the characteristics of hypotheses, substantiating the cost-benefit analysis, referring to:

- public officials' self-interest to participate in a corruption act only when they expect a positive net benefit for the transaction assumed by the corruption act;

- the implementation of anti-corruption strategies will reduce the expected gains and will increase the sanctions for corrupt behaviour.

Therefore, the authors conclude: "anti- corruption programs must change the cost-benefit calculations of public officials who believe that the expected net benefits of corruption are positive" (Huther and Shah, 2000, 2-3).

The above statements may be formalised in the relation:

$\mathrm{E}(\mathrm{B})=\mathrm{n} \times \mathrm{E}(\mathrm{G})-\operatorname{prob}[\mathrm{P}] \times[\mathrm{P}]>0$

where: $\quad \mathrm{E}$ is the expectations operator;

$\mathrm{n}$ is number of corrupt transactions;

$\mathrm{G}$ is the gain from the corrupt transaction;

Prob $[\mathrm{P}]$ is the probability of paying a penalty;

$\mathrm{P}$ is the penalty for the corrupt activity.

The relation (1) becomes essential for the assessment of anti-corruption strategies, determining the mechanisms that influence the corruption level:

- $\quad$ reducing the number of transactions involving public officials;

- reducing the possibilities of gains for each transaction;

- $\quad$ increasing the probability to pay penalties/sanctions for corrupt behaviour.

The factors influencing each element of the cost-benefit analysis are listed in Table 3.

$<$ Table 3 about here $>$

In view of assessing the anti-corruption strategies, the multiple objectives and actions enumerated in Table3, Huther and Shah $(2000,6)$ formulate two questions:

- $\quad$ how to establish the priorities of anti-corruption campaign;

- $\quad$ which actions should be used to meet those targets;

The answer may be substantiated differently.

From economic point of view, the priority actions should combat the reduction of welfare caused by corruption.

The authors state that operationalisation of such criteria of prioritization is difficult due to the fact that often the quantification of losses due to corruption is impossible and large losses are the result of multiple causes, including governance failure.

Therefore, prioritization of anti-corruption activities should rely on analysis of economic, political and bureaucratic conditions of every state.

Among the reasons for prioritization of the above-mentioned anti-corruption activities, Huther and Shah $(2000,7)$ present a quite diverse list:

- $\quad$ using the public opinion survey;

- $\quad$ reducing the size of public sector;

- increasing financial accountability;

- bureaucratic culture;

- decentralization;

- media independence;

- judicial independence;

- citizen participation. 


\subsubsection{OED methodology adapted in view to assess the anti-corruption strategies}

The same authors, Huther and Shah (2000, 8-12) present a new instrument for assessing the anti-corruption strategies, based on the methodology for assessing the development of states, achieved by Operations Evaluation Department (OED) and described by World Bank (2000).

The methodology is based on the use of four key criteria: relevance, efficacy, efficiency and sustainability. Tavistock Institute (2003) uses similar criteria and we find their application for assessing the local development in Matei, Matei and Savulescu (2010, 25-58).

In a brief description, in general terms, the mentioned criteria comprise:

- Relevance - it establishes a connection in a certain strategy and explicit objectives of a policy adopted by public decision. The evaluation of relevance is qualitative to a great extent.

- Efficacy may incorporate both qualitative and quantitative evaluations when analysing if the objectives stated in a development policy were achieved, the adequacy of the chosen solutions as well as the influence of external factors.

- Efficiency, usually, takes into consideration an economic evaluation, taking into consideration the costs associated, reported to the outcomes.

- Sustainability also uses qualitative evaluations, establishing the extent to which the impact of a policy meets the overall needs, the social, economic, political needs of community and/or state.

Referring to the anti-corruption strategies, Schacter and Shah (2000) sustain that the analysis on their relevance combines two factors: technical relevance and welfare relevance. "Technical relevance refers to the impact of specific activities on the incidence of corruption and the welfare relevance relates to the relative importance, for growth and poverty reduction of a particular type of corruption" (Huther and Shah, 2000, 8).

Taking into consideration the governance quality, (Huther and Shah, 1998; Kaufmann, Kraay and Zoido-Loboton, 1999), quantified by "weak", "fair", "good", Table 4. presents an assessment of the relevance of various anti-corruption programs.

\section{$<$ Table 4 about here $>$}

In view of assessing the anti-corruption strategies, efficacy will require a measurement of the effect of a certain set of anti-corruption activities on the level of corruption or corrupted activity.

On the other hand, an anti-corruption strategy will be considered efficient when it generates maximum reduction in the corruption incidence (good targeting), associated with welfare gains obtained with reduced costs.

Concerning sustainability, the anti-corruption activities are sustainable if they produce changes in the expectations on public officials' responsibilities.

Table 5 presents a relevant synthesis on the significance of the four criteria for assessing the anti-corruption strategies.

$<$ Table 5 about here $>$

The two instruments proposed by the World Bank for assessing the anti-corruption strategies should be accompanied, each time, by better knowledge about the realities in every state. In view of integrating those anti-corruption strategies in the strategies aimed at improving the governance quality, preliminary conclusions are configured and presented synthetically by the same authors in Table 6 .

$<$ Table 6 about here $>$

\subsection{Models developed by the European Bank for Reconstruction and Development (EBRD) - Steves - Rousso Model}

Steves and Rousso $(2003,4-7)$ present the methodology for assessing the anti-corruption strategies, developed by EBRD. In view to respond to concrete needs for assessing the anti-corruption strategies in former European communist states, the above authors' approach is correlated with other EBRD initiatives; EBRD together with World Bank achieved several rounds of Business Environment and Enterprise Performance Surveys (BEEPS). If we add the periodical evaluations, usually annual ones, on the level of corruption, achieved by World Bank, Transparency International or other transnational actors, we have a complex set of instruments, providing the possibility to assess the impact of anti-corruption strategies.

The below presentation follows closely the study of Steves - Rousso (2003); based on the main conclusions from the first and second BEEPS rounds, they have conceptualised and coded "a matrix of anti-corruption activities" (Steves and Rousso, 2003, 5). 
Those activities are divided in three general categories, as follows:

- omnibus reform programmes;

- new legislation targeted at anti-corruption;

- accession to international covenants and membership in international anti-corruption coalitions.

The above authors have developed, for each category, a grading system, representing the basis of calculation for an index specific for each category: Omnibus Index (OI), Legal Index (LI) and Conventions Index (CI).

Thus an anti-corruption matrix is obtained. Table 7 presents its variables and weights.

$<$ Table 7 about here $>$

At the same time, each category was divided in several specific criteria, based on specific activities in every country.

Consequently, for the activities specific to OI, an assessment is proposed.

OI.1-the design and publication of an anti-corruption strategy;

OI.2-the development of an implementing anti-corruption action plan;

OI.3-the establishment of a national anti-corruption commission, ombudsman or similar authority, aimed to coordinate and to monitor the achievement of objectives and activities from the national anti-corruption strategy.

For each criterion in the matrix, "1" was coded if the respective anti-corruption measures were introduced and " 0 " was coded if contrary.

As remarked in Table 7, these three major components of the OI are weighted equally.

The authors considered not only a formal consignment of the activities mentioned but also some aspects concerning their design, content and operationalization.

Thus, for each criterion there are sub criteria, as also remarked in Table 7. They refer mainly to:

- involving the non governmental organizations in developing the anti-corruption activities;

- complex structure of the strategy comprising several governmental branches or ministries such as that of justice, administration and home affairs etc;

- formal independence of anti-corruption commission/authority before the government.

For the activities specific to LI, concerning a new anti-corruption legislation, six criteria were developed on achieving, implementing or amending six laws, chosen on the basis of a careful observation of the specificity of the regulatory framework in the states mentioned.

Concerning CI, it evaluates the commitment of the states analysed to ratify and respect international conventions and standards, as well as their participation in international bodies and coalitions.

To refine this index, $1 / 3$ was given for signing the instrument, $2 / 3$ for signing and ratifying, and " 1 " if the document has been signed, ratified and has entered into force.

By aggregating these three indicators, an overall index will be obtained (Intensity Index for anti-corruption, II-AC), in view to evaluate the impact of the anti-corruption strategies in each state as well as to make comparisons and correlations with adjacent processes and phenomena, specific for the states analysed.

\section{A New Model for Assessing the Anti-corruption Strategies: Steves-Rousso Dynamic Model}

The analysis presented by Steves and Rousso (2003) referred to former communist states in transition and it covered the time horizon: 1999-2002. The quantification of activities in matrix had a single value for the whole period of time, determining us to consider this method as a static one.

In our view, the anti-corruption strategies and the whole ensemble accompanying them, represent the basis of a developing process in close accordance with the other processes characterising the reforms of societies in transition.

The experience shows that the internalization of new social rules in the public organizations, the implementation of the new mechanisms of social organization stipulated in the anti-corruption strategies require a longer period of time, being a process in development.

In this context, the new proposed model takes into consideration a longer period of reference (10 years) and the quantitative assessment of the anti-corruption actions is variable. 


\subsection{Dynamic matrix of anti-corruption activities ([A-C])}

Therefore, the dynamic matrix that we propose, will have variable annual quantifications, as follows:

- a series of Intensity Indices ([II-AC])- OI.1.1, OI.2.1, OI.3.1, OI.3.4 - as well as CI1-6 are quasi constant during the period analysed; they may vary only when the activities quantified are amended, modified or replaced with new ones. In this situation, it is valid the principle of overlapping the effects.

- the other II-AC vary annually in a linear way, since the year when they were adopted or integrated in the national legislative and institutional framework. Their values are cumulative and take into consideration eventual amendments, changes or replacements; it is also valid the principle of overlapping the effects.

- the dynamic matrix will have the same structure as the matrix proposed by Steves and Rousso and the weights (w) of each II-AC are maintained.

Methodologically, the matrix [A-C] will be determined as follows:

- a column will be allocated to each II-AC in [A-C];

- a number of rows equal to the number of years (n) during the period analysed will be allocated to every state analysed;

- based on the analysis of the anti-corruption activities in every state during the period analysed, a nominal support matrix will be drawn up, with the same structure as [A-C], marking for every II-AC, the relevant data on the year of adopting/setting up/ achieving the activities aimed by II-AC as well as the year of their changing/completing/restructuring (if applicable). Thus for every II-AC we obtain temporal data (years), $\mathrm{n} 1<\mathrm{n} 2$ $<\ldots \mathrm{nk}$ which will determine $\mathrm{k}$ periods, pi, when the activity corresponding to II-AC is stable $(\mathrm{pi}=\mathrm{n}-\mathrm{ni}, \mathrm{i}=$ $1,2, \ldots \mathrm{k})$

- $\quad$ Numerical values will be assigned annually for every II-AC and every state, as follows:

$>$ For quasi-constant indices, for every state and for every year during a period pi, a part wi from the weight (w) will be awarded, corresponding to II-AC, wi $=\mathrm{w} / \mathrm{k}$. For the periods overlapping, the numbers wi will be totalised, and 0 percentage will be allocated to the years belonging to no period.

For the variable linear indices, the allocation will be also annual-based and specific to every period. Unlike quasi-constant II-AC, in this case, in every period $\mathrm{p}_{\mathrm{i}}$, and every year, $\mathrm{n}_{\mathrm{i}}$, the allocation will be as follows:

$w_{i j}=\frac{w_{i}}{n}\left(n_{j}-n_{i}+1\right)$. As in the previous case, for the periods overlapping, the numbers $\mathrm{w}_{\mathrm{i}}$ will be totalised, and 0 percentage will be allocated to the years belonging to no period. Thus for every II-AC, we obtain increasing allocations, overlapped related to the periods of amending/updating the legislation, strategies etc. In the empiric example that we shall present below, we will remark, concretely, how we obtain the matrix [A-C]. We will find out that the matrix $[\mathrm{A}-\mathrm{C}]$ depends on the period of analysis and annually the values II-AC are usually increasing according to the thoroughness of the implementation for strategies, action plans, domestic and international legislation on anti-corruption actions.

\subsection{Empirical analysis of the national anti-corruption strategies in some South-Eastern European states}

The analysis presented below will have illustrative character in view of using the dynamic anti-corruption matrix.

The sample of analysed states comprises three EU Member States (Bulgaria (BG), Romania (RO) and Slovenia (SI)), an acceding state (Croatia (HR)) and other two South-Eastern European states (Moldova (MD) and Serbia (SE)). The sample also covers the Western Balkans as well as the former Soviet Union, respectively former Yugoslavia Federation.

The period analysed is 1999-2008.

Using the documentary database as well as sources quoted in Matei and Matei (2010), Annex 1 comprises the nominal support matrix for achieving $[\mathrm{A}-\mathrm{C}]$ in the above-mentioned states.

Annex 2 presents the effective calculation of II-AC as well as of primary indices - OI, LI and CI.

The overall remark is that the statistic variables associated both to primary indices and composite index II-AC have increasing values, fact which highlights the developing character of processes characterising the anti-corruption activities. 
The rhythms for the achievement and implementation of anti-corruption strategies are different. The calculation of statistic correlations reveals very high coefficients of correlation (between 0.939 (SI/HR) and 0.993 (MD/BG)); this fact is natural, taking into consideration the objectives of European integration of the respective states and compliance with the transnational anti-corruption frameworks, promoted by World Bank, OECD and, of course, EU.

We also remark the effects of enforcing the anti-corruption strategies in their correlation with the index of control of corruption (KKM), developed by the World Bank.

$<$ Table 8 about here $>$

The statistic correlations, described in Table 8 for 1999-2008 are relevant and demonstrate inverse negative correlations (MD, -0.339) or small positive correlations (BG, 0.306; SI, 0.375) or high correlations (HR, 0.663; RO, 0.801; SE, $0.890)$.

The conclusions of such findings are more profound and may lead to inadequacy of the anti-corruption strategies in some states, revealing an inappropriate perception of corruption as well as to inadequacy of the instrument of analysis. In fact, concerning this last conclusion, an explanation may be the difficulty of collecting data and information that reflect the actual reality in the states analysed.

At the same time, the quantitative analysis should be accompanied by a more refined qualitative analysis in view to emphasise other processes influencing the anti-corruption actions: political stability, courts of law, civil society etc.

The new model presented is closer to the realities in South-Eastern European states, and could represent the pillar of objective analyses on the developments in a certain state or comparative analyses.

\section{References}

Ades, A., Di Tella, R. (1999). Rents, Competition and Corruption. American Economic Review, 89 (4), pp. 982 - 993. doi:10.1257/aer.89.4.982, http://dx.doi.org/10.1257/aer.89.4.982

Andrei, T., Matei, A., Rosca, I. (2009). The Corruption - An Economic and Social Analysis. Economica Publishing House, Bucharest

Arrow, J.K. (1963). Uncertainty and the Welfare Economics of Medical Case. American Economic Review

Banfield, E.C. (1975). Corruption as a feature of governmental organisation. The Journal of Law and Economics, Vol XVIII(3), December.

Cobb, L., Gonzalez, M. (2005). Corruption as a system of interlocking cycles: Lessons from Nation Lab. Louisville CO, Aetheling Consultants

Gamboa - Cavazos, M., Garza - Cantu, V., Salinas, E. (2006). The Organization of Corruption. Political Horizons and Industrial Interests. Harvard University mimeo.

Getzen, T. (1997). Health Economics: Fundamentals and Flow of Fund. New York: Wiley

Hellman, J., Kaufmann, D., (2001), "Confronting the challenge of state capture in transition economies", Finance and Development, Vol 38, No 3, September, IMF

Huberts, LWJC, (1998), "What can be done against public corruption and fraud: expert views on strategies to protect public integrity", Crime, law \& social change 29, pp 209 - 224. doi:10.1023/A:1008348803253, http://dx.doi.org/10.1023/A:1008348803253

Huther, J., Shah, A., (1998), "A Simple Measure of Good Governance and its Application to the Debate on the Appropriate Level of Fiscal Decentralization”, World Bank Working Paper Series, No. 1894, Washington DC

Huther, J., Shah, A., (2000), “Anti-corruption Policies and Programs: A Framework for Evaluation”, World Bank Policy Research Working Paper, No. 2501, Available at SSRN: http://ssrn.com/abstract=632571

Karklins, R., (2005), "The system made me to do it: corruption in post - communist societies", Armonk NY, ME Sharpe

Kaufmann, D., Kraay, A., Mastruzzi, M., (2004), „Governance Matters: Governance Indicators for 1996 - 2002”, World Bank Policy Research Working Paper 3106.

Kaufmann, D., Kraay, A., Zoido - Lobaton, P., (1999), “Governance Matters”, World Bank Working Paper Series, No. 2196, Washington DC 
Matei, A., (2006), "A Model of Social and Economic Analysis of Corruption”, Theoretical and Applied Economics, Vol. 8, No. 6 (501), pp 39 - 46, Available at SSRN: http://ssrn.com/abstract=1327768

Matei, A., Matei, L., (2009), "Public Integrity and Performance of Governance. A Comparative Study for South Eastern Europe", Theoretical and Applied Economics, No. 7 (536), pp 3 - 28, Available at SSRN: http://ssrn.com/abstract $=1405185$

Matei, A., Matei, L., Savulescu, C., (2010), “Local Development, Theoretical and Empirical Models”, L.A.P. - Lambert Academic Publishing, Saarbrücken, Germany

Matei, A., Matei, L., (2010), "Integrating Anti-Corruption Strategies within the Government Reforms in some South-Eastern European States - An Empirical Study on the Impact of the Government Performance", International Conference "Public Management in $21^{\text {st }}$ Century: Opportunities and Challenges", Macau, China, Available at SSRN: http://ssrn.com/abstract=1669902

Matei, L., Matei, A., (2009), "Corruption in the Public Organization Towards a Model of Cost - Benefit Analysis for the Anti - corruption Strategies", Transylvanian Review of Administrative Sciences, No. 27 E/October, pp 145 - 171, Available at SSRN: http://ssrn.com/abstract $=1405209$

McCusker, R., (2006), "Review of Anti-corruption Strategies", Technical and Background Paper, No. 23, Australian Institute of Criminology, Canberra, Australia

Mueller, D.C., (ed), (1997), "Perspectives on Public Choice", Cambridge University Press, Cambridge

Persson, T., Tabellini, G., (2002), "Political Economy: Explaining Economic Policy”, MA: MIT Press, Cambridge

Rose-Ackerman, S., (2005), „Corruption and Government Causes, Consequences, and Reform”, Cambridge University Press.

Savedoff, D.W., (2004), ,' 40th Anniversary: Kenneth Arrow and the Birth of Health Economics”, Bulletin of the World Health Organization 82(2), February

Schacter, M., Shah, A., (2000), “Anti - corruption Programs: Look Before You Leap”, International Conference on Corruption, Seoul, South Korea

Shleifer, A., Vishny, R., (1993), „Corruption”, The Quarterly Journal of Economics, vol. 8, no.3, pp. 599-617. doi:10.2307/2118402, http://dx.doi.org/10.2307/2118402

Steves, Fr., Rousso, A., (2003), "Anti-corruption programmes in post - communist transition countries and changes in the business environment, 1999 - 2002", WP 85, European Bank for Reconstruction and Development (EBRD)

Tavistock Institute, GHK, IRS, (2003), "The Evaluation of Socio-Economic Development", http://www.evalsed.info

Tay, S., Seda, M., (eds), (2003), “The enemy within: combating corruption in Asia”, Singapore: Eastern Universities Press

UNDP, (1997), "Corruption and Good Governance”, New York

USAID, (2005), “Anti-corruption Strategy”, Washington DC

World Bank, (2000), “OED Methodology Syndicate - Evaluation Criteria Review”, Operations Evaluation Department (OED) 
Table 1. Importance of causes of public corruption and fraud

\begin{tabular}{|c|c|c|c|c|}
\hline \multicolumn{5}{|l|}{ Important cause } \\
\hline & \multicolumn{2}{|c|}{ Higher income country } & \multicolumn{2}{|c|}{ Lower income country } \\
\hline Factors & $\%$ & rank & $\%$ & rank \\
\hline Norms and values of politicians and public servants & 88.4 & 1 & 98.4 & 1 \\
\hline Lack of control, supervision, auditing & 87.2 & 2 & 93.3 & 2 \\
\hline Interrelationships - business, politics, state & 86.6 & 3 & 92.9 & 3 \\
\hline Values and norms concerning government/state & 84.6 & 4 & 79.7 & 11 \\
\hline Public sector culture (values/norms) & 83.3 & 5 & 76.8 & 12 \\
\hline Lack of commitment of leadership & 82.2 & 6 & 90.2 & 5 \\
\hline Misorganisation and mismanagement & 80.7 & 7 & 91.9 & 4 \\
\hline Increasing strength of organised crime & 79.3 & 8 & 90.0 & 7 \\
\hline Norms and values [in] private and public [life] & 78.0 & 9 & 73.7 & 14 \\
\hline Increasing significance of lobbying & 76.5 & 10 & 72.9 & 15 \\
\hline Interrelationships - politics and administration & 67.0 & 11 & 86.4 & 9 \\
\hline Social inequality & 66.7 & 12 & 90.2 & 6 \\
\hline Low salaries in the public sector & 56.9 & 16 & 87.1 & 8 \\
\hline Economic problems (inflation/recession) & 62.2 & 14 & 85.2 & 10 \\
\hline (n) & (190) & & (67) & \\
\hline
\end{tabular}

Source: Huberts (1998:7)

Table 2. Corruption winners and losers

\begin{tabular}{|c|c|c|c|}
\hline & Corrupter (A) & Corruptee (B) & Third Actor (C) \\
\hline 1 & Win & Win & Win \\
\hline 2 & Win & Win & Win \\
\hline 3 & Win & Lose & Lose \\
\hline 4 & Win & Lose & Win (anti-corruption goal) \\
\hline 5 & Lose & Win & Win (anti-corruption goal) \\
\hline 6 & Lose & Lose & Lose \\
\hline 7 & Lose & Win & Lose \\
\hline 8 & Lose & Lose & \\
\hline
\end{tabular}

Source: Karklins (2005: 150) 
Table 3. The influence of anti-corruption programs on officials' cost-benefit analysis

\begin{tabular}{|c|c|c|c|c|}
\hline $\begin{array}{c}\text { Number of } \\
\text { Corrupt } \\
\text { Transactions }\end{array}$ & $\begin{array}{c}\text { Gross Gains } \\
\text { from Corruption }\end{array}$ & $\begin{array}{l}\text { Probability of } \\
\text { Paying Penalty }\end{array}$ & $\begin{array}{l}\text { Magnitude of } \\
\text { Penalty }\end{array}$ & $\begin{array}{c}\text { Actions Not } \\
\text { Influencing } \\
\text { Cost Benefit } \\
\text { Analysis }\end{array}$ \\
\hline $\begin{array}{c}\text { Bureaucratic } \\
\text { Culture - } \\
\text { Streamlining } \\
\text { Services }\end{array}$ & $\begin{array}{c}\text { Economic Reform } \\
\text { - Improving } \\
\text { Competitive } \\
\text { Environment }\end{array}$ & $\begin{array}{c}\text { Anti- } \\
\text { Corruption } \\
\text { Agencies }\end{array}$ & $\begin{array}{l}\text { Rationalization } \\
\text { of laws }\end{array}$ & $\begin{array}{c}\text { Raising } \\
\text { Awareness of } \\
\text { Public through } \\
\text { Seminars }\end{array}$ \\
\hline $\begin{array}{c}\text { Creating or } \\
\text { Raising Public } \\
\text { Service Standards }\end{array}$ & $\begin{array}{l}\text { Scaling Down } \\
\text { Individual Public } \\
\text { Projects }\end{array}$ & $\begin{array}{c}\text { Parliamentary } \\
\text { Oversight }\end{array}$ & & $\begin{array}{l}\text { Public } \\
\text { Opinion } \\
\text { Surveys }\end{array}$ \\
\hline $\begin{array}{l}\text { Reducing Public } \\
\text { Employment }\end{array}$ & $\begin{array}{l}\text { Bureaucratic } \\
\text { Culture }\end{array}$ & Ombudsman & & $\begin{array}{l}\text { Raising Public } \\
\text { Sector Wages }\end{array}$ \\
\hline $\begin{array}{l}\text { Reducing Public } \\
\text { Sector Size }\end{array}$ & $\begin{array}{l}\text { Referenda on } \\
\text { Large Public } \\
\text { Projects }\end{array}$ & $\begin{array}{c}\text { Financial } \\
\text { Accountability }\end{array}$ & & $\begin{array}{l}\text { Reducing } \\
\text { Wage } \\
\text { Compression }\end{array}$ \\
\hline $\begin{array}{c}\text { Financial } \\
\text { Liberalization }\end{array}$ & & $\begin{array}{c}\text { Media } \\
\text { Independence }\end{array}$ & & \\
\hline $\begin{array}{c}\text { Increasing } \\
\text { Transparency }\end{array}$ & & $\begin{array}{c}\text { Judicial } \\
\text { Independence }\end{array}$ & & \\
\hline $\begin{array}{l}\text { Decentralization } \\
\text { of Public Services }\end{array}$ & & $\begin{array}{c}\text { Citizen } \\
\text { Participation }\end{array}$ & & \\
\hline \multirow[t]{2}{*}{$\begin{array}{l}\text { Economic Reform } \\
\text { - Privatization }\end{array}$} & & Rule of Law & & \\
\hline & & Ethics Office & & \\
\hline
\end{tabular}

Source: Huther and Shah $(2000,5)$

Table 4. Ratings on Relevance of a Menu of Anti-corruption Programs

\begin{tabular}{|l|c|c|c|l|}
\hline \multirow{2}{*}{ Program } & \multicolumn{2}{|c|}{ Country's Quality of Governance } & \multicolumn{2}{c|}{ Comments } \\
\cline { 2 - 4 } & Weak & Fair & Good & \\
\hline $\begin{array}{l}\text { Raising public } \\
\text { awareness of } \\
\text { corruption through } \\
\text { seminars }\end{array}$ & Not relevant & Low & Medium & $\begin{array}{l}\text { In countries with weak governance, corrupt } \\
\text { practices and agents are generally well known. }\end{array}$ \\
\hline $\begin{array}{l}\text { Raising awareness of } \\
\text { public officials through } \\
\text { seminars }\end{array}$ & Not relevant & Low & Medium & $\begin{array}{l}\text { Public officials may be aware of corruption } \\
\text { but unwilling and/or unable to take action } \\
\text { due to incentive problems in countries with } \\
\text { weak governance. }\end{array}$ \\
\hline $\begin{array}{l}\text { Anti-corruption } \\
\text { agencies /Ombudsman }\end{array}$ & Not relevant & Low & Medium & $\begin{array}{l}\text { With endemic corruption, anti-corruption } \\
\text { agencies or ombudsman may actually } \\
\text { extort rents. Positive influence if preconditions } \\
\text { for good governance exist. }\end{array}$ \\
\hline Ethics office & Not relevant & Low & Medium & $\begin{array}{l}\text { Positive influence may be limited to } \\
\text { societies with good governance. }\end{array}$ \\
\hline $\begin{array}{l}\text { Raising Public Sector } \\
\text { wages }\end{array}$ & Negligible & Low & Medium & $\begin{array}{l}\text { May have positive impact on petty } \\
\text { corruption but little impact on grand } \\
\text { corruption. Negative impact if part of } \\
\text { problem is excessive public employment. }\end{array}$ \\
\hline $\begin{array}{l}\text { Reducing Wage } \\
\text { Compression }\end{array}$ & Negligible & Negl. & Negligible & $\begin{array}{l}\text { More relevant as an incentive mechanism } \\
\text { for career development. May increase } \\
\text { corruption if the public sector viewed as } \\
\text { lucrative career option by greedy elements } \\
\text { of society. }\end{array}$ \\
\hline Merit based civil service & Low & Medium & High & $\begin{array}{l}\text { May be derailed by bureaucratic processes } \\
\text { in highly corrupt societies. }\end{array}$ \\
\hline Public Opinion Surveys & Low & Medium & Medium & Public opinion surveys have served as a \\
\hline
\end{tabular}




\begin{tabular}{|c|c|c|c|c|}
\hline & & & & $\begin{array}{l}\text { useful tool in articulating citizens' } \\
\text { concerns (e.g. Bangalore scorecard). }\end{array}$ \\
\hline Financial accountability & Low & Low & Medium & $\begin{array}{l}\text { Medium appropriate when democratic } \\
\text { accountability and a substantial } \\
\text { accounting/bookkeeping infrastructure } \\
\text { with some integrity are in place. }\end{array}$ \\
\hline Parliamentary oversight & Low & Medium & Medium & $\begin{array}{l}\text { Parliamentary oversight can be helpful but } \\
\text { parliamentary micro-management not an } \\
\text { effective form of governance. }\end{array}$ \\
\hline $\begin{array}{l}\text { Reducing Public } \\
\text { Employment }\end{array}$ & Medium & Low & Low & May reduce opportunities for corruption \\
\hline Decentralization & Medium & Low & Low & $\begin{array}{l}\text { May improve accountability and may } \\
\text { increase sense of social purpose for public } \\
\text { officials. }\end{array}$ \\
\hline $\begin{array}{l}\text { Client-based civil } \\
\text { service / Bureaucratic } \\
\text { culture }\end{array}$ & Medium & Medium & Low & $\begin{array}{l}\text { Success depends upon service delivery } \\
\text { orientation of public service, reinforced by } \\
\text { accountability for results. }\end{array}$ \\
\hline Economic policy reform & High & Medium & Low & $\begin{array}{l}\text { Reduces potential corruption by shifting } \\
\text { decision-making to the private sector. }\end{array}$ \\
\hline $\begin{array}{l}\text { Media and judicial } \\
\text { independence, citizen } \\
\text { participation }\end{array}$ & High & Medium & Low & $\begin{array}{l}\text { Allows for detection, followed by } \\
\text { accountability. }\end{array}$ \\
\hline $\begin{array}{l}\text { Reducing Public Sector } \\
\text { Size }\end{array}$ & High & Medium & Low & $\begin{array}{l}\text { By reducing the number of government } \\
\text { activities, officials can focus on primary } \\
\text { objectives of the state. }\end{array}$ \\
\hline Rule of law & High & Medium & Low & Essential for any progress. \\
\hline
\end{tabular}

Source: Huther and Shah $(2000,9-10)$

Table 5. Summary of Proposed Rating Factors for Anti-Corruption Programs

\begin{tabular}{|c|c|c|}
\hline Relevance & $\checkmark$ & $\begin{array}{l}\text { Program objectives consistent with country's development priorities, with } \\
\text { Bank strategy } \\
\text { Program design underpinned by analytical work that recognizes country } \\
\text { specific public sector mission and values, opportunities and constraints and an } \\
\text { informed view of potential impacts of alternative actions } \\
\text { Judgments as to (a) the degree to which the anti-corruption programs were } \\
\text { targeted to corruption drivers; (b) the relationship between those drivers, } \\
\text { corruption and welfare outcomes. }\end{array}$ \\
\hline Efficacy & $\checkmark$ & $\begin{array}{l}\text { The extent to which the project's objectives were achieved, or expected to be } \\
\text { achieved, taking into account their relative importance in curtailing corruption. } \\
\text { Judgments to be made about the degree to which Bank supported interventions } \\
\text { have (i) reduced, (ii) had no impact, or (iii) led to an increase in, levels of } \\
\text { various forms of corruption in the country. As a proxy focus on the } \\
\text { relationship between Bank supported interventions and changes in key } \\
\text { corruption drivers. }\end{array}$ \\
\hline Efficiency & $\checkmark$ & $\begin{array}{l}\text { generates most reductions in corruption and associated welfare gains for the } \\
\text { least cost } \\
\text { targets corruption that has large costs }\end{array}$ \\
\hline Sustainability & & $\begin{array}{l}\text { the resilience to risk of net benefit flows over time based upon an assessment } \\
\text { of political, economic, financial, social and external influences }\end{array}$ \\
\hline
\end{tabular}

Source: Huther and Shah $(2000,11)$ 
Table 6. Effective Anti-Corruption Programs Based on Governance Quality

\begin{tabular}{|c|c|l|}
\hline $\begin{array}{c}\text { Incidence of } \\
\text { Corruption }\end{array}$ & $\begin{array}{c}\text { Governance } \\
\text { Quality }\end{array}$ & Priorities of Anti-Corruption Efforts (Based on Drivers of corruption) \\
\hline High & Poor & $\begin{array}{l}\text { Establish rule of law, strengthen institutions of participation and } \\
\text { accountability; limit government interventions to focus on core mandate }\end{array}$ \\
\hline Medium & Fair & $\begin{array}{l}\text { Decentralization and economic policy reforms; results-oriented } \\
\text { management and evaluation; introduction of incentives for competitive } \\
\text { public service delivery }\end{array}$ \\
\hline Low & Good & $\begin{array}{l}\text { Explicit anti-corruption programs such as anti-corruption agencies; } \\
\text { strengthen financial management; raising public and officials awareness; no } \\
\text { bribery pledges, fry big fish, etc. }\end{array}$ \\
\hline
\end{tabular}

Source: Huther and Shah $(2000,12)$

Table 7. Anti-corruption matrix variables and weighting

\begin{tabular}{|c|c|c|c|c|c|}
\hline Intensity Index (II-AC) & Notation & $\begin{array}{c}\text { Weight } \\
\text { (W) }\end{array}$ & Intensity Index (II-AC) & Notation & $\begin{array}{c}\text { Weight } \\
\text { (W) }\end{array}$ \\
\hline Omnibus Index & $\mathrm{OI}$ & 33.4 & Legal Index & LI & 5.55 \\
\hline $\begin{array}{c}\text { National anti-corruption } \\
\text { strategy }\end{array}$ & OI1 & 11.2 & Civil Service Law & LI.1 & 5.55 \\
\hline Adopted & OI1.1 & 5.56 & Financial Disclosure Law & LI.2 & 5.55 \\
\hline Involved NGOS & OI1.2 & 2.78 & Public Procurement Law & LI.3 & 5.55 \\
\hline Multi-branch & OI1.3 & 2.78 & Freedom of Information Law & LI.4 & 5.55 \\
\hline Anti-corruption action plan & OI2 & 11.1 & Party Finance Law & LI.5 & 5.55 \\
\hline Adopted & OI2.1 & 5.55 & Anti-Money Laundering Law & LI.6 & 5.55 \\
\hline Involved NGOS & OI 2.2 & 2.78 & Conventions Index* & $\mathrm{CI}$ & 33.3 \\
\hline Multi-branch & OI2.3 & 2.78 & $\begin{array}{c}\text { Stability Pact anti-Corruption } \\
\text { Initiative }\end{array}$ & CI.1 & 5.55 \\
\hline $\begin{array}{c}\text { Anti-corruption commission or } \\
\text { ombudsmen }\end{array}$ & $\mathrm{OI} 3$ & 11.1 & OECD Anti-Bribery Convention & CI.2 & 5.55 \\
\hline Established & OI3.1 & 5.56 & COE GRECO & CI.3 & 5.55 \\
\hline Involved NGOS & OI3.2 & 1.11 & $\begin{array}{l}\text { COE Convention on Laundering, } \\
\text { Search, Seizure and } \\
\text { Confiscation of the Proceeds } \\
\text { from Crime }\end{array}$ & CI.4 & 5.55 \\
\hline Multi-branch & OI3.3 & 1.11 & $\begin{array}{c}\text { COE Criminal Law Convention } \\
\text { on Corruption }\end{array}$ & CI.5 & 5.55 \\
\hline Independent & OI3.4 & 3.33 & $\begin{array}{c}\text { COE Civil Law Convention on } \\
\text { Corruption }\end{array}$ & CI.6 & 5.55 \\
\hline
\end{tabular}

*In the non-Stability Pact countries, the other five indicators in this Index represent 6.66 per cent of the Intensity Index.

Source: Steves and Rousso $(2003,6)$. 
Table 8. Correlations II-AC/KKM

\begin{tabular}{|l|l|r|r|r|r|r|r|}
\hline & & BG_KKM & HR_KKM & MD_KKM & RO_KKM & SE_KKM & SI_KKM \\
\hline BG_II_AC & Pearson Correlation & .306 & .562 & -.308 & $.863\left(^{* *}\right)$ & $.929\left(^{* *}\right)$ & .201 \\
\hline & Sig. (2-tailed) & .390 & .091 & .387 & .001 & .000 & .577 \\
\hline & N & 10 & 10 & 10 & 10 & 10 & 10 \\
\hline HR_II_AC & Pearson Correlation & .385 & $.663\left(^{*}\right)$ & .420 & $\left..8044^{(* *}\right)$ & $\left..8922^{* *}\right)$ & .093 \\
\hline & Sig. (2-tailed) & .272 & .036 & .227 & .005 & .001 & .798 \\
\hline & $\mathrm{N}$ & 10 & 10 & 10 & 10 & 10 & 10 \\
\hline MD_II_AC & Pearson Correlation & .341 & .586 & -.339 & $.862\left(^{* *}\right)$ & $.906\left(^{* *}\right)$ & .204 \\
\hline & Sig. (2-tailed) & .335 & .075 & .338 & .001 & .000 & .571 \\
\hline & $\mathrm{N}$ & 10 & 10 & 10 & 10 & 10 & 10 \\
\hline RO_II_AC & Pearson Correlation & .348 & .602 & .356 & $\left..8011^{* *}\right)$ & $\left..9011^{* *}\right)$ & .146 \\
\hline & Sig. (2-tailed) & .325 & .065 & .313 & .005 & .000 & .688 \\
\hline & $\mathrm{N}$ & 10 & 10 & 10 & 10 & 10 & 10 \\
\hline SE_II_AC & Pearson Correlation & .363 & .617 & -.376 & $.829\left(^{(* *}\right)$ & $\left..8900^{* *}\right)$ & .120 \\
\hline & Sig. (2-tailed) & .302 & .057 & .284 & .003 & .001 & .742 \\
\hline & N & 10 & 10 & 10 & 10 & 10 & 10 \\
\hline SI_II_AC & Pearson Correlation & .340 & .487 & .251 & $.848\left(^{* *}\right)$ & $.921\left(^{* *}\right)$ & .375 \\
\hline & Sig. (2-tailed) & .336 & .154 & .485 & .002 & .000 & .286 \\
\hline & N & 10 & 10 & 10 & 10 & 10 & 10 \\
\hline
\end{tabular}

** Correlation is significant at the 0.01 level (2-tailed).

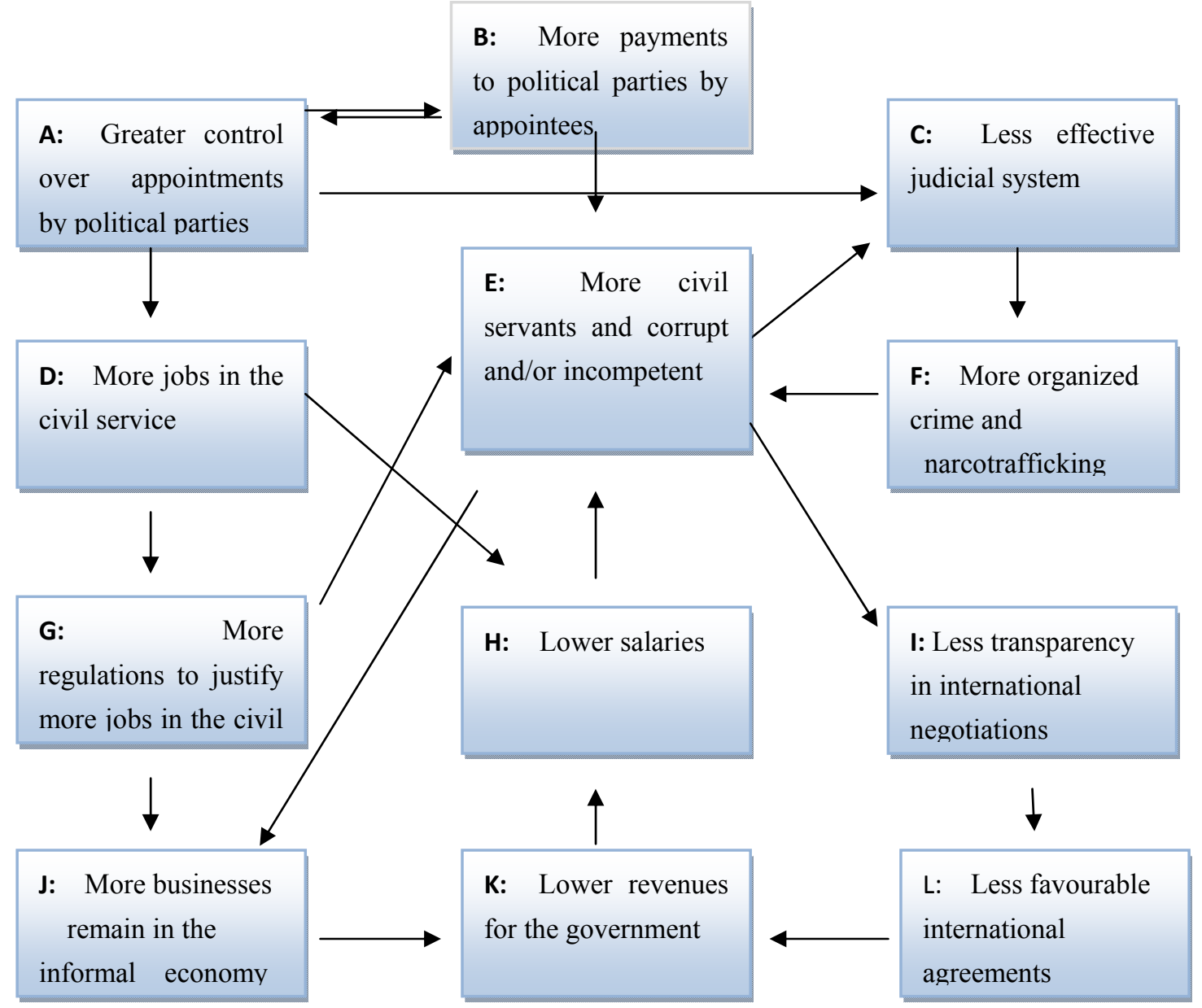

Figure 1. Corruption as a system of interlocking vicious cycles

Source: (Cobb \& Gonzalez 2005, 6) 
Annex 1: Nominal support matrix for II-AC

\begin{tabular}{|c|c|c|c|c|c|c|c|c|c|c|c|c|c|c|c|c|c|c|c|c|c|c|c|}
\hline \multirow{3}{*}{ State } & \multirow{3}{*}{ Year } & \multicolumn{3}{|c|}{ Omnibus Index OI1 } & \multicolumn{3}{|c|}{ Omnibus Index OI2 } & \multicolumn{4}{|c|}{$\begin{array}{c}\text { Omnibus } \\
\text { Index OI3 }\end{array}$} & \multicolumn{6}{|c|}{ Legal Index LI } & \multicolumn{6}{|c|}{ Conventions Index CI } \\
\hline & & OI & OI & OI & OI & OI & OI & OI & OI & OI & OI & LI & $\mathrm{LI}$ & $\overline{\mathrm{LI}}$ & LI & LI & LI & $\mathrm{CI}$ & $\mathrm{CI}$ & & & $\mathrm{CI}$ & $\mathrm{CI}$ \\
\hline & & 1.1 & 1.2 & 1.3 & 2.1 & 2.2 & 2.3 & 3.1 & 3.2 & 3.3 & 3.4 & 1 & 2 & 3 & 4 & 5 & 6 & 1 & 2 & 3 & 4 & 5 & \\
\hline 0 & 1 & 2 & 3 & 4 & 5 & 6 & 7 & 8 & 9 & 10 & 11 & 12 & 13 & 14 & 15 & 16 & 17 & 18 & 19 & 20 & 21 & 22 & 23 \\
\hline $\mathrm{BG}$ & 1999 & & & & & & & & & & & $\mathrm{x}$ & & & & & $\mathrm{x}$ & $\mathrm{x}$ & $\mathrm{x}$ & $\mathrm{x}$ & & & \\
\hline BG & 2000 & & & & & & & & & & & & & & $\mathrm{x}$ & & & & & & $\mathrm{x}$ & $\mathrm{x}$ & $\mathrm{x}$ \\
\hline BG & 2001 & $\mathrm{x}$ & $\mathrm{x}$ & $\mathrm{x}$ & & & & & & & & $\mathrm{X}^{*}$ & $\mathrm{x}$ & $\mathrm{x}$ & & $\mathrm{x}$ & & & & & & & \\
\hline BG & 2002 & & & & $\mathrm{x}$ & $\mathrm{x}$ & $\mathrm{x}$ & $\mathrm{x}$ & $\mathrm{x}$ & $\mathrm{x}$ & $\mathrm{x}$ & & & & $\mathrm{X}^{*}$ & & & & & & & & \\
\hline BG & 2003 & & & & & & & & & & & & & & & & & & & & & & \\
\hline BG & 2004 & & & & $\mathrm{X}^{*}$ & $\mathrm{X}^{*}$ & $\mathrm{X}^{*}$ & & & & & & & & & & & & & & & & \\
\hline BG & 2005 & & & & & & & $\mathrm{X}^{*}$ & $\mathrm{X}^{*}$ & $\mathrm{X}^{*}$ & $\mathrm{X}^{*}$ & & & & $\mathrm{X}^{*}$ & $\mathrm{X}^{*}$ & & & & & & & \\
\hline $\mathrm{BG}$ & 2006 & $\mathrm{X}^{*}$ & $\mathrm{X}^{*}$ & $\mathrm{X}^{*}$ & & & & & & & & & & & $\mathrm{X}^{*}$ & & & & & & & & \\
\hline BG & 2007 & & & & & & & & & & & $\mathrm{X}^{*}$ & & & & & $\mathrm{X}^{*}$ & & & & & & \\
\hline BG & 2008 & & & & & & & & & & & & & & & & & & & & & & \\
\hline HR & 1999 & & & & & & & & & & & & & & & & & $\mathrm{x}$ & & & & & \\
\hline $\mathrm{HR}$ & 2000 & & & & & & & & & & & $\mathrm{x}$ & & & & & & & & $\mathrm{x}$ & $\mathrm{x}$ & $\mathrm{x}$ & $\mathrm{x}$ \\
\hline $\mathrm{HR}$ & 2001 & & & & & & & $x$ & $\mathrm{x}$ & $\mathrm{x}$ & $x$ & & & $x$ & $\mathrm{x}$ & & & & & & & & \\
\hline $\mathrm{HR}$ & 2002 & $\mathrm{x}$ & $\mathrm{x}$ & $\mathrm{x}$ & $\mathrm{x}$ & $\mathrm{x}$ & $\mathrm{x}$ & & & & & & & & & & & & & & & & \\
\hline HR & 2003 & & & & & & & & & & & & & $\mathrm{X}^{*}$ & $\mathrm{X}^{*}$ & & $\mathrm{x}$ & & & & & & \\
\hline HR & 2004 & & & & & & & & & & & & & & & & & & & & & & \\
\hline $\mathrm{HR}$ & 2005 & $\mathrm{X}^{*}$ & $\mathrm{X}^{*}$ & $\mathrm{X}^{*}$ & $\mathrm{X}^{*}$ & $\mathrm{X}^{*}$ & $\mathrm{X}^{*}$ & & & & & & & & & & & & & & & & \\
\hline $\mathrm{HR}$ & $\frac{2005}{2006}$ & & & & & & & & & & & $\mathrm{X}^{*}$ & & & & & & & & & & & \\
\hline 0 & 1 & 2 & 3 & 4 & 5 & 6 & 7 & 8 & 9 & 10 & 11 & 12 & 13 & 14 & 15 & 16 & 17 & 18 & \begin{tabular}{|l|}
19 \\
\end{tabular} & 20 & 21 & 22 & 23 \\
\hline HR & 2007 & & & & & & & & & & & & & & & & & & & & & & \\
\hline HR & 2008 & & & & & & & & & & & & & & & & $\mathrm{X}^{*}$ & & & & & & \\
\hline MD & & & & & & & & & & & & $\mathrm{x}$ & & $\mathrm{x}$ & & $\mathrm{x}$ & & $\mathrm{x}$ & & $x$ & & & \\
\hline MD & & & & & & & & & & & & & $x$ & & $\mathrm{x}$ & & & & & & $x$ & $x$ & $\mathrm{x}$ \\
\hline MD & 2001 & & & & & & & $\mathrm{x}$ & $\mathrm{x}$ & $x$ & $\mathrm{x}$ & & & & & & $x$ & & & & & & \\
\hline MD & 2002 & & & & & & & & & & & & & & & & & & & & & & \\
\hline MD & 2003 & & & & & & & & & & & & & & & & & & & & & & \\
\hline $\mathrm{MD}$ & 200 & $\mathrm{x}$ & $\mathrm{x}$ & $\mathrm{x}$ & $\mathrm{x}$ & $\mathrm{x}$ & $\mathrm{x}$ & & & & & & & & & & & & & & & & \\
\hline MD & 2005 & & & & & & & & & & & & & & & & & & & & & & \\
\hline MD & 2006 & & & & $\mathrm{X}^{*}$ & $\mathrm{X}^{*}$ & $\mathrm{X}^{*}$ & & & & & & & & & & & & & & & & \\
\hline MD & 2007 & & & & & & & & & & & & & & & & $\mathrm{X}^{*}$ & & & & & & \\
\hline MD & 2008 & & & & & & & & & & & & & & & & & & & & & & \\
\hline RO & 1999 & & & & & & & & & & & $\mathrm{x}$ & & $\mathrm{x}$ & & $\mathrm{x}$ & $\begin{array}{l}x \\
\end{array}$ & & & $\begin{array}{l}x \\
\end{array}$ & & & \\
\hline RO & 2000 & & & & & & & & & & & & & & & & & $\mathrm{x}$ & & & $\mathrm{x}$ & & \\
\hline $\mathrm{RO}$ & 2001 & $\mathrm{x}$ & $\mathrm{x}$ & $\mathrm{x}$ & $\mathrm{x}$ & $\mathrm{x}$ & $\mathrm{x}$ & $\mathrm{x}$ & $\mathrm{x}$ & $\mathrm{x}$ & & & & & $\mathrm{x}$ & & & & & & & $\mathrm{x}$ & $\mathrm{x}$ \\
\hline RO & 2002 & & & & & & & $\mathrm{X}^{*}$ & $\mathrm{X}^{*}$ & $\mathrm{X}^{*}$ & & & & & & & $\mathrm{X}^{*}$ & & & & & & \\
\hline RO & 2003 & & & & & & & & & & & & & & & $\mathrm{X}^{*}$ & & & & & & & \\
\hline RO & 2004 & & & & & & & & & & & & & & & & & & & & & & \\
\hline RO & 2005 & $\mathrm{X}^{*}$ & $\mathrm{X}^{*}$ & $\mathrm{X}^{*}$ & $\mathrm{X}^{*}$ & $\mathrm{X}^{*}$ & $\mathrm{X}^{*}$ & $\mathrm{X}^{*}$ & $\mathrm{X}^{*}$ & $\mathrm{X}^{*}$ & & & & & & & $\mathrm{X}^{*}$ & & & & & & \\
\hline RO & 2006 & & & & & & & & & & & $\mathrm{X}^{*}$ & & $\mathrm{X}^{*}$ & & & $\mathrm{X}^{*}$ & & & & & & \\
\hline
\end{tabular}




\begin{tabular}{|c|c|c|c|c|c|c|c|c|c|c|c|c|c|c|c|c|c|c|c|c|c|c|c|}
\hline RO & 2007 & & & & & & & & & & & & & & & & & & & & & & \\
\hline RO & 2008 & & & & & & & & & & & & & & & & & & & & & & \\
\hline SE & 1999 & & & & & & & & & & & & & & & & & & & & & & \\
\hline SE & 2000 & & & & & & & & & & & & & & & & & $\mathrm{x}$ & & & $\mathrm{x}$ & $\mathrm{x}$ & $\mathrm{x}$ \\
\hline 0 & 1 & 2 & 3 & 4 & 5 & 6 & 7 & 8 & 9 & 10 & 11 & 12 & 13 & 14 & 15 & 16 & 17 & 18 & 19 & 20 & 21 & 22 & 23 \\
\hline SE & 2001 & $\mathrm{x}$ & $\mathrm{x}$ & $x$ & $\mathrm{x}$ & $x$ & $x$ & $x$ & $x$ & $x$ & $\mathrm{x}$ & & & & & & & & & & & & \\
\hline SE & 2002 & & & & & & & & & & & & & $\mathrm{x}$ & & & & & & & & & \\
\hline SE & 2003 & & & & & & & & & & & & & & & $\mathrm{x}$ & & & & $\mathrm{x}$ & & & \\
\hline SE & 2004 & & & & & & & & & & & & & & $\mathrm{x}$ & & & & & & & & \\
\hline SE & 2005 & $\mathrm{X}^{*}$ & $\mathrm{X}^{*}$ & $\mathrm{X}^{*}$ & $\mathrm{X}^{*}$ & $\mathrm{X}^{*}$ & $\mathrm{X}^{*}$ & & & & & $\mathrm{x}$ & & & & & $\mathrm{x}$ & & & & & & \\
\hline SE & 2006 & & & & & & & & & & & & & & & & & & & & & & \\
\hline SE & 2007 & & & & & & & & & & & & & & & & & & & & & & \\
\hline SE & 2008 & & & & & & & & & & & & & & & & & & & & & & \\
\hline SI & 1999 & & & & & & & & & & & & & & & & & & & $x$ & & & \\
\hline SI & 2000 & & & & & & & & & & & & & & & & & & & & & & \\
\hline SI & 2001 & & & & & & & & & & & & & $\mathrm{X}$ & & $\mathrm{x}$ & & & $\mathrm{x}$ & & $\mathrm{x}$ & $\mathrm{x}$ & $x$ \\
\hline SI & 2002 & & & & & & & & & & & $\mathrm{x}$ & $\mathrm{x}$ & & $\mathrm{x}$ & & & & & & & & \\
\hline SI & 2003 & & & & & & & & & & & & & & & & & & & & & & \\
\hline SI & 2004 & $x$ & $\mathrm{x}$ & $\mathrm{x}$ & $\mathrm{x}$ & $\mathrm{x}$ & $\mathrm{x}$ & $\mathrm{x}$ & $\mathrm{x}$ & $\mathrm{x}$ & $\mathrm{x}$ & & & & & & & & & & & & \\
\hline SI & 2005 & & & & & & & & & & & & & & $\mathrm{X}^{*}$ & & & & & & & & \\
\hline SI & 2006 & & & & & & & & & & & & & $\mathrm{X}^{*}$ & & & & & & & & & \\
\hline SI & 2007 & & & & & & & & & & & & & & & & $\mathrm{x}$ & & & & & & \\
\hline SI & 2008 & & & & & & & & & & & & & & & & & & & & & & \\
\hline
\end{tabular}

Legend: new attribute, modified or amended $\mathrm{X}^{*}$

Source: the authors

Annex 2: Numerical quantification for II-AC

\begin{tabular}{|c|c|c|c|c|c|c|c|c|c|c|c|c|c|c|c|c|c|c|c|c|c|c|c|c|c|c|c|}
\hline \multirow[b]{2}{*}{ State } & \multirow[b]{2}{*}{ Year } & \multicolumn{11}{|c|}{ Omnibus Index OI } & \multicolumn{7}{|c|}{ Legal Index LI } & \multicolumn{7}{|c|}{ Conventions Index CI } & \multirow{2}{*}{$\Sigma$} \\
\hline & & OI & OI & OI & OI & OI & OI & OI & OI & OI & OI & $\sum \mathrm{OI}$ & LI & LI & LI & LI & $\mathrm{LI}$ & LI & $\sum \mathrm{LI}$ & $\mathrm{CI}$ & $\mathrm{CI}$ & $\mathrm{CI}$ & $\mathrm{CI}$ & $\mathrm{CI}$ & $\mathrm{CI}$ & $\Sigma \mathrm{CI}$ & \\
\hline 0 & 1 & $\frac{1.1}{2}$ & $\frac{1.2}{3}$ & $\frac{1.3}{4}$ & $\frac{2.1}{5}$ & $\frac{2.2}{6}$ & $\frac{2.3}{7}$ & $\begin{array}{c}3.1 \\
8\end{array}$ & $\frac{3.2}{9}$ & $\frac{3.3}{10}$ & $\frac{3.4}{11}$ & 12 & $\frac{1}{13}$ & $\frac{2}{14}$ & $\frac{3}{15}$ & $\begin{array}{l}4 \\
16\end{array}$ & $\frac{5}{17}$ & $\begin{array}{c}6 \\
18\end{array}$ & 19 & $\frac{1}{20}$ & $\frac{2}{21}$ & $\frac{3}{22}$ & $\frac{4}{23}$ & $\frac{5}{24}$ & $\frac{6}{25}$ & 26 & 27 \\
\hline $\mathrm{BG}$ & 1999 & & $\frac{-}{-1}$ & & & & & & & & & & 0.18 & & & & & 0.28 & 0.46 & 5.56 & 5.56 & $\frac{22}{5.56}$ & & & & 16.68 & 17.14 \\
\hline $\mathrm{BG}$ & 2000 & & & & - & & - & - & & & & & 0.36 & & & 0.14 & & 0.56 & 1.06 & 5.56 & 5.56 & 5.56 & 5.56 & 5.56 & 5.56 & 33.36 & 34.42 \\
\hline $\mathrm{BG}$ & 2001 & 2.78 & 0.14 & 0.14 & & & & & & & & 3.06 & 0.72 & 0.56 & 0.56 & 0.28 & 0.28 & 0.84 & 3.24 & 5.56 & 5.56 & 5.56 & 5.56 & 5.56 & 5.56 & 33.36 & 39.66 \\
\hline $\mathrm{BG}$ & 2002 & 2.78 & 0.28 & 0.28 & 2.78 & 0.14 & 0.14 & 2.78 & 0.06 & 0.06 & 1.66 & 10.96 & 1.08 & 1.11 & 1.11 & 0.56 & 0.56 & 1.12 & 5.54 & 5.56 & 5.56 & 5.56 & 5.56 & 5.56 & 5.56 & 33.36 & 49.86 \\
\hline $\mathrm{BG}$ & 2003 & 2.78 & 0.42 & 0.42 & 2.78 & 0.28 & 0.28 & 2.78 & 0.11 & 0.11 & 1.66 & 11.62 & 1.44 & 1.67 & 1.67 & 0.84 & 0.84 & 1.4 & 7.86 & 5.56 & 5.56 & 5.56 & 5.56 & 5.56 & 5.56 & 33.36 & 52.84 \\
\hline $\mathrm{BG}$ & 2004 & 2.78 & 0.56 & 0.56 & 5.56 & 0.56 & 0.56 & 2.77 & 0.17 & 0.17 & 1.66 & 15.36 & 1.80 & 2.22 & 2.22 & 1.12 & 1.12 & 1.68 & 10.16 & 5.56 & 5.56 & 5.56 & 5.56 & 5.56 & 5.56 & 33.36 & 58.88 \\
\hline $\mathrm{BG}$ & 2005 & 2.78 & 0.70 & 0.70 & 5.56 & 0.84 & 0.84 & 5.56 & 0.28 & 0.28 & 3.33 & 20.87 & 2.16 & 2.78 & 2.78 & 1.54 & 1.40 & 1.96 & 12.62 & 5.56 & 5.56 & 5.5 & 5.56 & 5.56 & 5.56 & 33.36 & 66.85 \\
\hline $\mathrm{BG}$ & 2006 & 5.56 & 0.98 & 0.98 & 5.56 & 1.12 & 1.12 & 5.56 & 0.39 & 0.39 & 3.33 & 24.99 & 2.52 & 3.34 & 3.34 & 2.10 & 1.96 & 2.24 & $\frac{1.202}{15.50}$ & 5.56 & 5.56 & 5.56 & 5.56 & 5.56 & 5.56 & $\frac{35.36}{33.36}$ & 73.85 \\
\hline $\mathrm{BG}$ & 2007 & 5.56 & 1.24 & 1.24 & 5.56 & 1.40 & 1.40 & 5.56 & 0.50 & 0.50 & 3.33 & 26.29 & 3.06 & 3.89 & 3.89 & 2.66 & 2.52 & 2.52 & 18.54 & 5.56 & 5.56 & 5.56 & 5.56 & 5.56 & 5.56 & 33.36 & 78.14 \\
\hline $\mathrm{BG}$ & 2008 & 5.56 & 1.54 & 1.54 & 5.56 & 1.68 & 1.68 & 5.56 & 0.61 & 0.61 & 3.33 & 27.67 & 3.6 & 4.45 & 4.45 & 3.22 & 3.08 & 3.08 & 21.88 & 5.56 & 5.56 & 5.56 & 5.56 & 5.56 & 5.56 & 33.36 & 82.91 \\
\hline HR & 1999 & & & & & & & & & & & & & & & & & & & 5.56 & & & & & & 5.56 & 5.56 \\
\hline HR & 2000 & - & - & - & - & - & - & & & & & & 0.28 & & 0.28 & 0.28 & 0.56 & - & 1.40 & 5.56 & - & 5.56 & 5.56 & 5.56 & 5.56 & 27.80 & 29.20 \\
\hline HR & 2001 & & & & & & & 5.56 & 0.11 & 0.11 & 3.33 & 9.11 & 0.56 & - & 0.56 & 0.56 & 1.12 & - & 2.80 & 5.56 & - & 5.56 & 5.56 & 5.56 & 5.56 & 27.80 & 39.71 \\
\hline HR & 2002 & 2.78 & 0.14 & 0.14 & 2.78 & 0.14 & 0.14 & 5.56 & 0.22 & \begin{tabular}{|l|l|}
0.22 \\
\end{tabular} & 3.33 & 15.45 & 0.84 & & 0.84 & 0.84 & 1.68 & & 4.2 & 5.56 & - & 5.56 & 5.56 & 5.56 & 5.56 & 27.80 & 47.45 \\
\hline
\end{tabular}


